\title{
The Impact of Hydro Climatic Variability on Water Resources of Lake Chad Hydro Graphic Basin
}

Xia Jun* and Allaramadji Beyaitan Bantin

Wuhan University, Wuhan, Hubei, China

\begin{abstract}
This study shows the impact of hydro climatic variability on water resources in the Lake Chad watershed. The application of Nicholson and Maillet methods and statistical tests for homogeneity (Buishand's, Hubert's, Lee and Heghinian's and Pettitt tests) made it possible to demonstrate a climatic variability characterized by alternation Wet, normal and dry season with a long deficit period that began around 1977 and resulted in an impoverishment of water resources in Chad. This decline in rainfall decreases the flow of water that passes through the Lake Chad basin. According to the Buishand test, this decrease in water level is marked by a very significant break, which oscillates between $90 \%$ and $95 \%$ in the years 1982 for the stations assumed in the center of study area such as Moundou and Bousso. The study found that in the 1960s Lake Chad covered an area of $25,000 \mathrm{~km}^{2}$, under the combined effect of climate change, its surface area shrank to $2,500 \mathrm{~km}^{2}$ in 2004 . This hydro-climatic variability has a negative impact on agricultural, pastoral and fisheries activities and is a major threat to the population living around this basin. The results of this study showed that large variations in water levels and landscapes are directly dependent on rainfall in the Chari basin and it is possible to indicate that agricultural production, access to food in the years to come, be seriously compromised by climate change resulting in wide variability in the availability of water resources.
\end{abstract}

Keywords: Impact; Hydro-climatic; Variability; Water resources; Basin; Lake Chad

\section{Introduction}

In recent years, the question of hydro-climatic variability is a challenge for the world and for Africa in particular. It is explained by factors inherent to the climate system and the climatic variability greatly affects water resources with consequences on various sectors of activity.

A study of the impact of hydro-climatic variability on the Lake Chad Basin becomes essential in identifying solutions to save this lakeChad which was once one of the largest lakes in the world and has considerably reduced during the Four decades.

According to historians, during the post-glacial periods, the Sahara benefited from the climatic condition which was more lenient than at those currently experienced and the real desert was very restricted. Depending on the alternations between the wet and dry periods, Lake Chad extends or shrinks, but from 1970 to the present day, the decline of the waters has accelerated, corresponding to the aridity and the advance of the desert. Climate change and increased anthropogenic pressure on earth-atmosphere interactions affect water quantity, quality, and waterrelated processes, such as sediment yield, on local, regional, and global scales [1].

This climate change affects the availability of water resources with consequences that are important for water management.

Over the past 40 years, the Chari/Logon river system discharge in the N'Djamena city of Chad has decreased by almost $75 \%$, which has considerably reduced the supply in the lake [2].

Freshwater ecosystems are particularly threatened by this hydroclimatic variability as increasing water temperatures, decreasing runoff and drying wetlands have resulted in the loss of a significant number of amphibian species or other aquatic species.

The different aspects related to food security (availability, accessibility, a stability of supply, use) are influenced by socioeconomic changes and also by quantitative and qualitative changes in water resources under climate change.

\section{Study Area}

The Lake Chad basin is located between $12^{\circ} 20^{\prime}$ and $14^{\circ} 20^{\prime}$ latitude and $13^{\circ}$ and $15^{\circ} 20^{\prime}$ longitude in the center of Africa, on the Southern edge of the Sahara Desert. It is said to be the remnant of the paleochad and at a time when the African tropical climate was more humid, the lake stretched far to the north of Africa [3]. The Lake Chad itself is a terminal depression with only four of the basin countries (Nigeria, Niger, Chad and Cameroon) in direct contact with it. The lake occupies less than 1 percent of the drainage basin [4]. At $25,000 \mathrm{~km}^{2}$ open water area in the 1960s, Lake Chad was the world's sixth largest inland water body [5] (Figure S1).

This basin is characterized by an annual rainfall that varies between 100 and $300 \mathrm{~mm}$, oscillates between $200 \mathrm{~mm}$ in the North and $1200 \mathrm{~mm}$ in the extreme south of the basin. Its infiltration is very low, estimated from 200 to $400 \mathrm{~mm}$ per year. Its average temperature varies between $15^{\circ} \mathrm{C}$ and $45^{\circ} \mathrm{C}$ with a maximum of more than $50^{\circ} \mathrm{C}$ recorded under the shadow near the lake, whereas humidity increases from 10 to $20 \%$ in the North in the dry season and 90 to $100 \%$ in the south during the rainy season.

Lake Chad is located in the Inter-Tropical Convergence Zone (ZCIT), a meeting point between the air masses of the high-pressure zones of the northern hemispheres (anticyclone of the Azores) and south (anticyclone of Sainte Helene). It is south of the maximum of convergence that triggers the rains or the lines of grains. The Inter-

${ }^{*}$ Corresponding author: Xia Jun, Wuhan University, Wuhan, Hubei, 430072, China, Tel: +862768773772/+861064889312; E-mail: xiajun666@whu.edu.cn

Received August 23, 2017; Accepted September 06, 2017; Published September 13, 2017

Citation: Jun X, Bantin AB (2017) The Impact of Hydro Climatic Variability on Water Resources of Lake Chad Hydro Graphic Basin. Hydrol Current Res 8: 282. doi: 10.4172/2157-7587.1000282

Copyright: ( 2017Jun X, et al. This is an open-access article distributed under the terms of the Creative Commons Attribution License, which permits unrestricted use, distribution, and reproduction in any medium, provided the original author and source are credited. 
Tropical Convergence Zone moves northward from January to July and flows back south from July to January. The magnitude of the rainy season, in quantity and duration, depends on the magnitude of migration in the Convergence Zone, which can vary significantly from year to year.

This non-salt freshwater basin is divided between Cameroon in the south $(8 \%)$, Niger in the north-west (17\%), Nigeria in the west $(25 \%)$ and Chad in the east (50\%). It is the fourth largest lake in Africa and the third endorheic lake in the world. Lake Chad spreads in a low depressed closed basin with an average depth of 1.5 to $5 \mathrm{~m}$. It is one of the most humid areas of the Sahel, extremely rich in natural resources and plays a major role in hydrology, economy, and ecology with a biodiversity reserve of world interest. This is justified by the number of species living in this area. There are about 21 species of fish in the Lake Chad Basin [6]. Approximately 372 species of birds have been recorded in this area, of which one-third are species that migrate (Palaearctic) and tropical poles (Table 1).

\section{Data Collection and Analysis}

\section{Data collection}

The methodological approach used is based on annual rainfall data, reports from the Lake Chad Basin Commission (LCBC) and data from other structures. The rainfall data used are those of the Bongor, Bousso, Moundou, Ndjamena and Sarh stations (Figure 1). The rainfall data used are those of the Bongor, Bousso, Moundou, Ndjamena and Sarh rainfall stations. They cover the period 1950-2010 and come from the Directorate General of National Meteorology of Chad (DGNM). These five stations were selected to monitor the temporal variability of precipitation due to their long series and good quality.

\section{Analysis}

In order to carry out this study, two methods were used: a graphical method based on the analysis of the evolution of rainfall indices weighted moving averages and drying coefficients and a statistical method based on the use of statistical tests, Homogeneity (detection of breaks) and trend.

The analysis of hydro-climatic variability required the use of several software programs: Excel, Khronostat 1.01 (available free on the Internet), drying coefficients were calculated using the EVC software, and the rainfall index from The Nicholson method.

\section{Study Methods of Hydro-Climatic Variability}

The study of hydro-climatic variability was carried out by analyzing data collected at five stations such as Bongor, Bousso, Moundou, N'Djamena and Sarh. Based on the analysis of rainfall variability, periods of rainfall deficit rainfall over time and space have been identified. The evolution of precipitation was carried out by the method of calculating the NICHOLSON rainfall index and the low-pass filter method of "HANNING of order 2".

\section{Nicholson rainfall index}

It makes it possible to observe rainfall variations over a long period of observations. The calculation of this index was carried out on the five stations of the study area for a period of 60 years of observation.

The Nicholson index is expressed by the following formula:

$$
I_{p}=\frac{X_{i}-X_{m}}{\sigma}
$$

With:

\begin{tabular}{|c|c|c|}
\hline Inputs $\left(\mathrm{Km}^{\mathbf{3}}\right.$ /year) & $\mathbf{1 9 5 4 - 1 9 6 9}$ & $\mathbf{1 9 8 8 - 2 0 1 0}$ \\
\hline Chari & 42 & 21.1 \\
\hline El Beida & 1.5 & 0.3 \\
\hline Komadougou Yobé & 0.7 & 0.5 \\
\hline Direct rainfall & 7.4 & 1.9 \\
\hline Losses (Km $\mathbf{3}$ /year) & \multicolumn{2}{|l|}{} \\
\hline Evaporation & 48.8 & 22.6 \\
\hline Net infiltration & 2.3 & 1 \\
\hline Overflow & 0.2 & 0 \\
\hline
\end{tabular}

Table 1: The water balance expressed in $\mathrm{km}^{3} /$ year.

$\mathrm{I}_{\mathrm{p}}$ : rainfall or hydrological index

$\mathrm{X}_{\mathrm{i}}$ : annual module of the variable recorded during year $\mathrm{i}$

$\mathrm{X}_{\mathrm{m}}$ : Interannual mean of the variable over the period of study

$\sigma:$ Standard deviation of the hydro-climatic series over the period of study.

\section{Hanning low pass filter 2}

For Hanning's Low Pass filter method, the first step is to filter the data to eliminate seasonal variations. This filter is made using the recommended equations. According to this method, each term in the series is calculated as follows:

$$
X(t)=0.06 x_{(t-2)}+0.25 x_{(t-1)}+0.38 x_{(t)}+0.25_{(t+1)}+0.06_{(t+2)}
$$

With:

$\mathrm{X}(\mathrm{t}): \mathrm{X}(\mathrm{t})$ is the weighted rainfall total of the term $\mathrm{t} ; \mathrm{X}_{(\mathrm{t}-2)}$ and $\mathrm{X}_{(\mathrm{t}-\mathrm{f}}$ ${ }_{1}$ : total observed flows of two terms immediately preceding the term t. $\mathrm{X}_{(\mathrm{t}+2)}$ and $\mathrm{X}_{(\mathrm{t}+1)}$ : observed rainfall totals of two terms immediately following the term $t$. The first two $\left[\mathrm{X}_{(1)}, \mathrm{X}_{(2)}\right]$ and the last two $\left[\mathrm{X}_{(\mathrm{n}-1)}, \mathrm{X}_{(\mathrm{n})}\right]$ terms of the series are calculated using the following expressions (being the size of the series):

$$
\begin{aligned}
& X_{(1)}=0.54 X_{(1)}+0.46 X_{(2)} \\
& X_{(2)}=0.25 X_{(1)}+0.5 X_{(2)}+0.25 X_{(3)} \\
& X_{(n-1)}=0.25 X_{(n-2)}+0.5 X_{(n-1)}+0.25 X_{(n)} \\
& X_{(n)}=0.54 X_{(n)}+0.46 X_{(n-1)}
\end{aligned}
$$

To better visualize periods of a deficit and excess flow, moving averages are centered and reduced by the following formula:

$$
Y_{t}^{\prime}=\left(X_{(t)}-m\right) / \sigma
$$

Where: $m$ is the average of the series of weighted averages and $\sigma$ is the standard deviation of the series of weighted moving averages.

\section{Break detection statistical methods}

Statistical treatment by the application of fracture detection tests was used to analyze and synthesize the time series of precipitation. The tests used are extracted from the study. Their choice is justified by the robustness of their procedure and by the fact that they have already been applied to hydrometric series observed in Sudano-Sahelian Africa. These tests make it possible to check the randomness of the series of variables and to detect a possible break in the time series.

Pettitt's test: The Pettitt test is nonparametric and is derived from the MANNWHITNEY test.

The absence of a break in the series $\left(\mathrm{X}_{\mathrm{i}}\right)$ of size $\mathrm{N}$ constitutes the null hypothesis. Implementation of the test assumes that for any instant $t$ between 1 and $\mathrm{N}$, the time series $\left(\mathrm{X}_{\mathrm{i}}\right)$, from $\mathrm{i}=1$ to $\mathrm{t}$ and from 


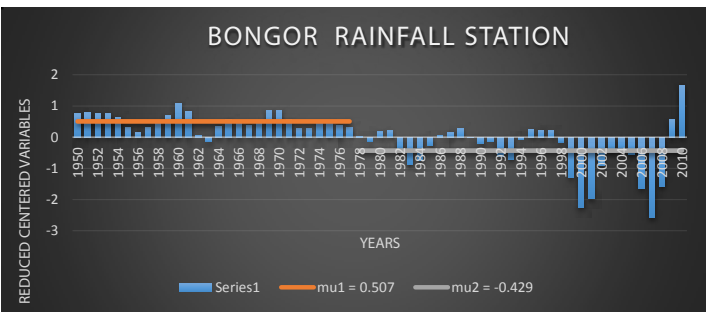

A Bongor rainfall station

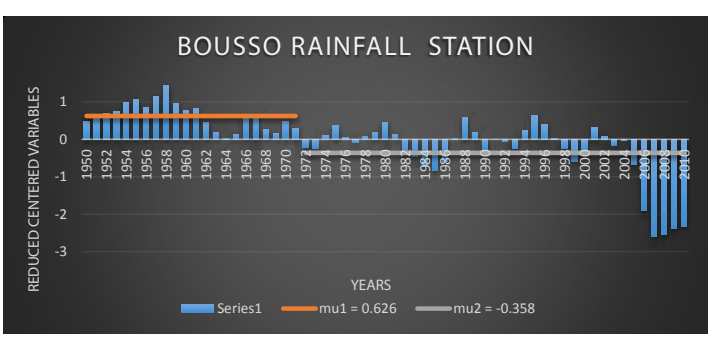

B Bousso rainfall station

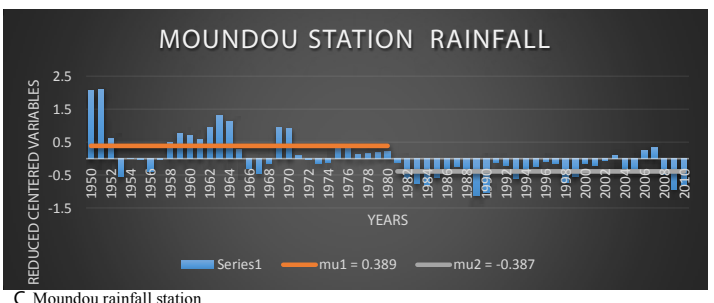

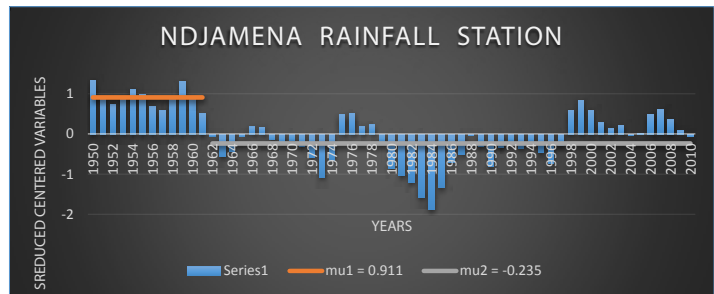

D NDjamena rainfall station

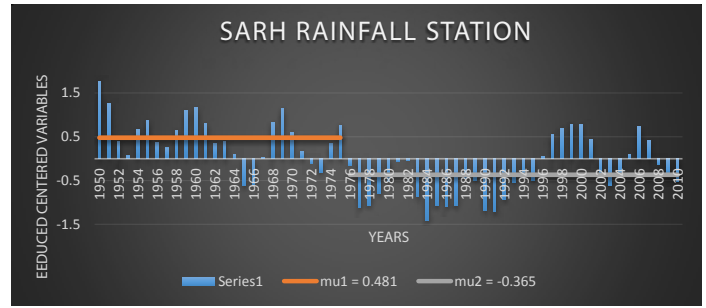

E Sarh rainfall station

Legends:

$$
\begin{aligned}
& \text { - Rainfall series } \\
& \text { - Wet period } \\
& \text { - Dry period }
\end{aligned}
$$

Figure 1: Annual rainfall for the five stations.

$\mathrm{t}+1$ to $\mathrm{N}$ belong to the same population. The variable to be tested is the maximum in absolute value

Of the variable $\mathrm{U}_{\mathrm{t}}, \mathrm{N}$ defined by:

$U_{t, N}=\sum_{i=1}^{t} \sum_{j=t+1}^{N} D_{i j}$

Where: $D_{i j}=\operatorname{sgn}\left(\mathrm{X}_{\mathrm{i}}-\mathrm{X}_{\mathrm{j}}\right)$, with $\operatorname{sgn}(\mathrm{X})=1$ if $\mathrm{X}>0$ if $\mathrm{X}=0$ and -1 if $\mathrm{X}<0$.

In the case where the null hypothesis is rejected, an estimate of the break-up date is given by the instant $t$ defining the maximum in an absolute value of the variable $\mathrm{U}_{\mathrm{t}^{\prime} \mathrm{N}}$.

Bayesian method of Lee and Heghinan: The Bayesian method of Lee and Heghinian (1977) aims to confirm or invalidate the hypothesis of an average change in the series. The absence of rupture in the series constitutes the null hypothesis. The procedure is based on the following model:

$$
X_{i}=\left\{\begin{array}{c}
\mu+\varepsilon_{i} i=1 \ldots . \tau \ldots \\
\mu+\delta+\varepsilon_{i} i=\tau+1 \ldots \ldots \ldots . .
\end{array}\right.
$$

where the $\varepsilon_{i}$ are independent and normally distributed, with zero mean and variance $\sigma^{2}$. The variables $\tau, \mu, \delta$ and $\sigma$ are unknown parameters. $\mathrm{T}$ and $\delta$ represent respectively the position of the rupture in time and the amplitude of the change in the mean. The method thus provides the probability that the break occurs at time $\tau$ in a series where it is assumed a priori that there is indeed a change at an unspecified time (Table 2).

Hubert segmentation: To understand the impact of hydro-climatic variability, we applied the Hubert segmentation to the studied series.

The Hubert segmentation method (Hubert et al.) of the time series is appropriate for the search for multiple mean changes in the same series (Table 3).

This method consists in dividing the series in $\mathrm{m}$ segment so that the average calculated on any segment is significantly different from the average of the neighboring segment(s).

According to the authors (Hubert et al.), for a given order, the selected segmentation has the smallest quadratic difference between the segmentation considered and the series.

Let $(\mathrm{k}=1,2, . ., \mathrm{m})$ be in the initial series of the terminal end of the kth segment, nk the length (=Ik-ik-1) of the $\mathrm{k}^{\text {th }}$ segment and $\mathrm{Xk}$ the mean of the $\mathrm{k}^{\text {th }}$ segment, the quadratic deviation $\mathrm{D}_{\mathrm{m}}$ between the segmentation considered and the series is given by the expression:

$D_{m}=\sum_{k=1}^{m} d_{k}$ où $d_{k}=\sum_{t=i_{k-1}+1}(X i-\bar{X} k)^{2}$

This method can be considdered as a stationary test where the null hypothesis is "the studied series is stationary. In this case, if the procedure does not produce an acceptable segment of order greater than or equal to 2 , the null hypothesis is accepted. There is no meaning level associated with this method.

Calculation of mean variables: For hydro-climatic variations with a time series of rupture, it is important to calculate the mean variations on both sides of the rupture by applying the following equation:

$$
D=X_{j} / X_{i}-1
$$

where $\mathrm{X}_{\mathrm{j}}$ represents the mean over the period after the rupture and $\mathrm{X}_{\mathrm{i}}$ the average over the period before the break.

Precipitation study using the Principal Component Analysis 
(CSPA): The variability of precipitation in Chad has been studied from the CSPA. This analysis was carried out on inter-annual rainfall. The 5 rainfall stations in the region were used as variables and the statistical units are represented by years. The period concerned starts from 1950 to 2010 , or 60 descriptors.

Study of the drying up of Lake Chad: The study of the dryingoff of Lake Chad was carried out using the calculation of the drying coefficient.

Calculation of the drying coefficient: Maillet's law and dichotomous method: According to the relation between surface water and groundwater, it is important to know the evolution of groundwater reserves during possible climatic variations.

For this calculation, we used the method of Maillet improved by the dichotomy resolution. The mathematical expression is:

$$
Q_{t}=Q_{0} e^{-k t}
$$

where, $Q_{t}$ is the flow rate at the given instant $t, Q_{0}$ the initial flow rate (flow at the beginning of drying) and $\mathrm{k}$ the drying coefficient of Maillet.

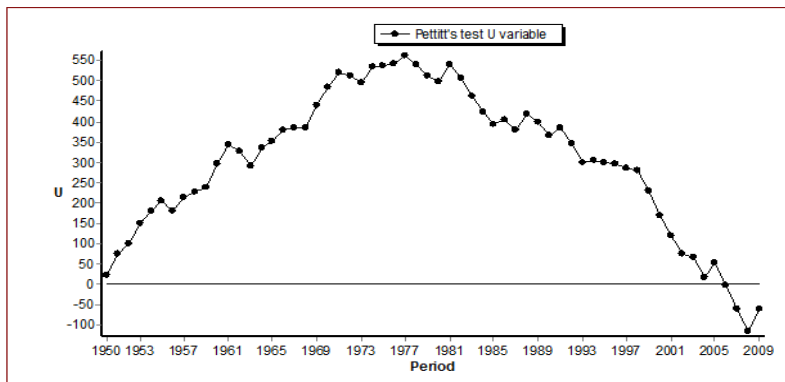

Bongor station

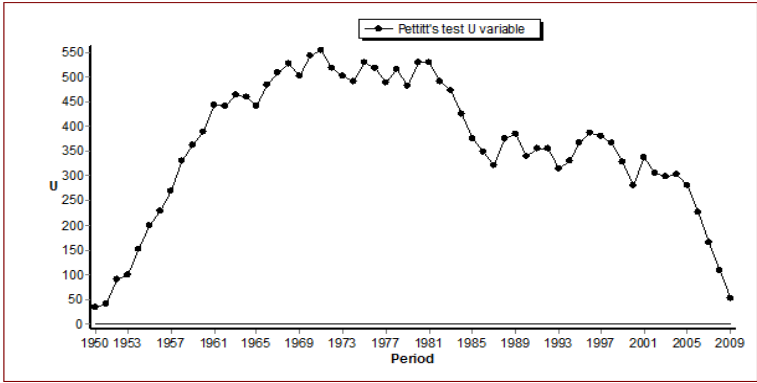

Bousso station

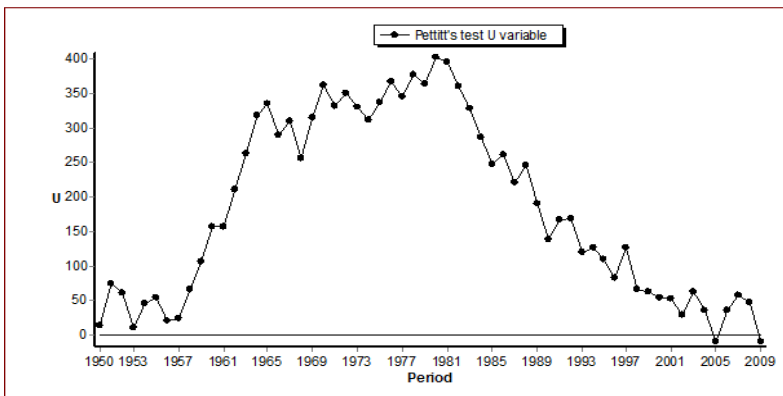

Moundou station
In the dichotomous method, it is estimated that the annual drying curve is the expression of the emptying of the underground reservoir. The quantity of water recovered at the gauging station corresponds exclusively to the dynamic volumes (V) mobilized by all the aquifers in the basin. The equation of the drying coefficient $(\mathrm{k})$ is written:

$$
\frac{e^{-k t}}{k}+\frac{V}{Q_{0}}-\frac{1}{k}=0
$$

With: $\mathrm{V}$ the volume at each instant $\left(\mathrm{m}^{3}\right)$.

Assessment of the volume mobilized by aquifers: The volume mobilized by all the aquifers of the watershed is given by the equation:

$$
V_{\text {mobilize }}=\int_{0}^{+\infty} Q_{0} e^{-k t} d t=\frac{Q_{0}}{k}
$$

where $\mathrm{Q}_{0}$ is expressed in $\mathrm{m}^{3} /$ day and $\mathrm{k}$ in $\mathrm{j}^{-1}$.

\section{Results and Discussion}

\section{Results}

Hydroclimatic variability on lake chad basin: The evolution of the Nicholson indices associated with seasonal elimination by Hanning

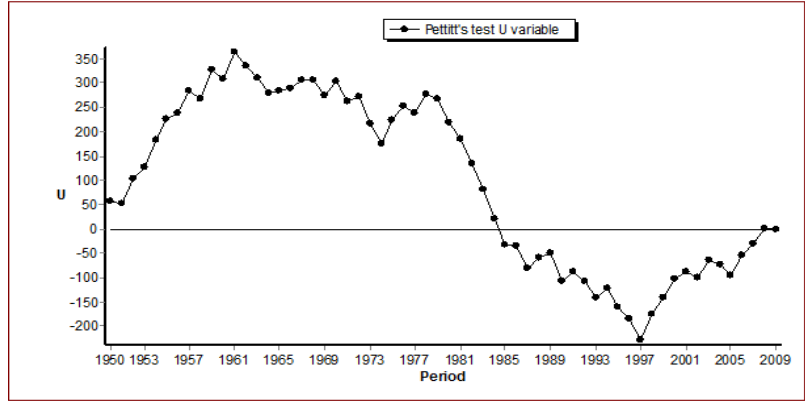

Ndjamena station

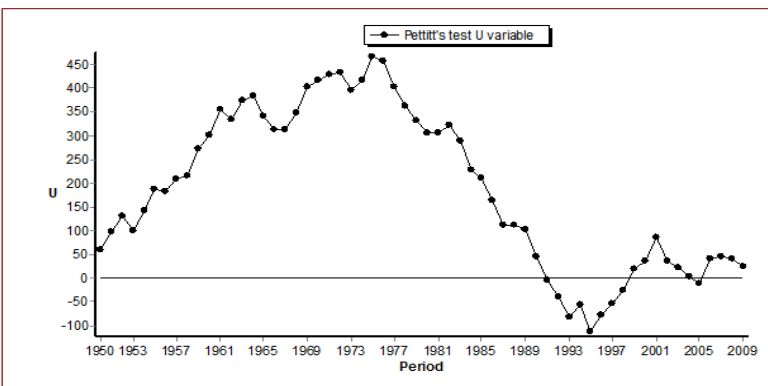

Sarh station

Figure 2: Pettitt's test. 
filter shows that inter-annual variations in rainfall at the Bongor, Bousso, Ndjamena, Moundou and Sarh stations are characterized by alternating wet, normal years and dry season.

The hydrometric variability studied in Bongor, Bousso, Moundou, Ndjamena, and Sarh through the evolution of the reduced centered indices, doubled by Hanning filtering, makes it possible to distinguish the periods of fluctuations of the annual modules from the following flow rates:

- a 1959-1961 surplus period for the Bongor station, 1957-1959 for the Bousso station, 1962-1964 for Moundou, 1958-1960 for the station of Ndjamena and 1958-1961 for the Sarh rainfall station is marked by an abundance of flows, indicates a wet period;

- a deficit period of 1982-1985; 1998-2008 for the Bongor station, 1982-1986; 1998-2000 for the station of Bousso, from 1982-2002 for the rainfall station of Moundou, from 1958-1974; 1979-1977 for the station of N'djamena and of 1976-1995 for the station of Sarh which corresponds to a dry period marked by a great drop of the flows of the river in particular in the years 1982;

- a 2009-2010 surplus period for the Bongor station announces a return of moisture at the end of the observation period.

Detection of breakdown hydrometric series: The result of the Pettitt test made it possible to identify ruptures in the rainfall series (Figure 2; Tables 4 and 5). The null hypothesis of absence of failure was rejected at the $99 \%, 95 \%$, and $90 \%$ confidence thresholds. These breaks were identified in 1977 for Bongor station and in 1971 for Bousso station. The identification of these years of ruptures makes it possible to distinguish two periods of fluctuations in rainfall over the basin. An overall wet period before 1977 (Bongor) and 1971 (Bousso) and a dry period after these dates. Unlike rainfall, the flow series studied shows no major breaks. Indeed, the null hypothesis of absence of rupture is accepted for the three confidence thresholds (Figure 3).

\section{Extent of drought}

The Lake Chad basin is part of the Sahel, a semi-arid region susceptible to drought.

Among the climatic cataclysms that have affected our planet in recent decades, the drought that hit Chad in 1973 has been particularly felt in the field of agriculture, ecology and also has a preponderant place

\begin{tabular}{|c|c|c|}
\hline Stations & Year of Break & Probability associated \\
\hline Bongor & 0 & 0 \\
\hline Bousso & 2005 & 0.913 \\
\hline Moundou & 1951 & 0.1952 \\
\hline N'Djamena & 1961 & 0.4061 \\
\hline Sarh & 1975 & 0.1317 \\
\hline
\end{tabular}

Table 2: Rupture of rainfall series according to the Lee and Heghinian test.

\begin{tabular}{|c|c|c|c|c|}
\hline \multirow{2}{*}{ Stations } & Period of & \multicolumn{3}{|c|}{ Dates of Occurrences of Breaks } \\
\cline { 3 - 5 } & observation & Pettitt's Test & $\begin{array}{c}\text { The Bayesian } \\
\text { method of Lee and } \\
\text { Heghinan }\end{array}$ & $\begin{array}{c}\text { Hubert } \\
\text { Segmentation }\end{array}$ \\
\hline Bongor & $1950-2010$ & 1977 & No rupture & 1977 \\
\hline Bousso & $1950-2010$ & 1971 & 2005 & 2005 \\
\hline Moundou & $1950-2010$ & 1980 & 1951 & 2010 \\
\hline Ndjamena & $1950-2010$ & 1961 & 1961 & 1959 \\
\hline Sarh & $1950-2010$ & 1975 & 1975 & 1975 \\
\hline
\end{tabular}

Table 3: Hubert segmentation test. in the drying up of Lake Chad (Table 6).

This exceptional drought experienced in 1972-1973 transformed the hydrology of the Lake Chad Basin and its effects on the fish stock were catastrophic [7].

educed rainfall, which is accompanied by a decline in river flows and soil moisture, are the different factors of this drought.

It can be seen that too much rainfall falls on a soil that is too dry and gives rise to very low run-off and infiltrates in large quantities and does not reach the water table, thus the basin of the Chari and the Logone which contributes to food of the lake are deficient and their intake becomes low (Figure 4).

The SPI index also allowed us to characterize the severity of the drought in southern Chad, the cause of which is hydro-climatic variability. However, we emphasize the existence of three sequences of drought.

Interactions between changing precipitation regimes and other aspects of global change are likely to affect natural and managed terrestrial ecosystems as well as human society [8]. This disaster caused much controversy about his cause. On the one hand, climatologists have offered a variety of assumptions to account for observed rainfall variations. These assumptions include Bryson's suggestions that human intake of dust and carbon dioxide into the atmosphere changes the atmospheric circulation of the wind in a manner that could permanently decrease Sahelian rainfall [9].

\section{The drying up of lake chad}

The sharp decline in rainfall and the upper surface of the groundwater is, therefore, the cause of a profound change in the flow regime by a chronic underground water supply deficit, because in recent decades the groundwater stock is insufficiently renewed by the rains.

Changes in runoff and groundwater in shallow aquifers are part of hydrological processes that can be linked to climate variability, with implications for permanent and seasonal water bodies such as lakes and reservoirs [10]. In this situation, it is noted that this phenomenon has not only occurred on the groundwater but also on the cuvettes. Indeed, Lake Chad is represented by three reservoirs including the northern basin, an archipelago of the southern basin and basin south. During the 1980 s, the northern basin was often dry, sometimes for over a year, and its water surface varied from 0 to $6,000 \mathrm{~km}^{2}$. The total surface area of the lake has been low, especially with the drying of the northern basin in the 1980s, particularly during the low annual waters, with minimums below $2,000 \mathrm{~km}$. The northern basin evolves independently of that of the southern basin with a rapid decline at first.

The consequence of climatic variations divides Lake Chad into three phases even though it remains one of the largest lakes in Africa:

- The great Lake Chad, in 1963 , covers an area of $25,000 \mathrm{~km}^{2}$ with an altitude of more than $282.3 \mathrm{~m}$ and a slight overflow to the northeast through the Bahr El-Ghazal;

- The Middle Lake Chad has a body of water covering 15,000 to $20,000 \mathrm{~km}^{2}$ with an altitude of 280 to $282 \mathrm{~m}$ and an archipelago of some 2,000 dune islands, a limited marshy vegetation on the shores;

- The small Lake Chad consists of several separate water bodies during at least part of the year and covers $2,500 \mathrm{~km}^{2}$ in 2004 .

Lake Chad has been operating as a small lake since 1975. While 


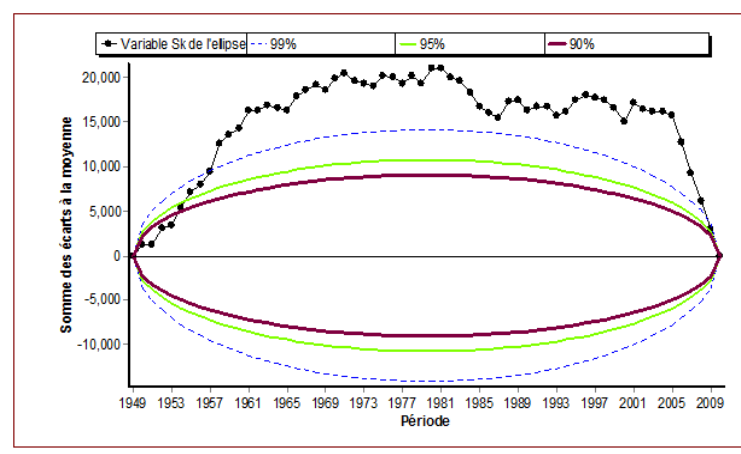

A. Bousso rainfall station

Null hypothesis (No break) rejected at the confidence level of $99 \%$

Null hypothesis (No break) rejected at the confidence level of $95 \%$

Null hypothesis (No break) rejected at the confidence level of $90 \%$

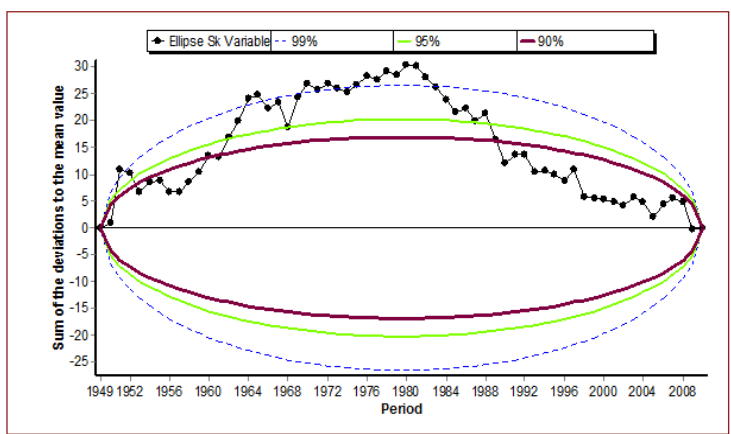

B. Moundou rainfall station

Null hypothesis (No break) rejected at the confidence level of $99 \%$

Null hypothesis (No break) rejected at the confidence level of $95 \%$

Null hypothesis (No break) rejected at the confidence level of $90 \%$

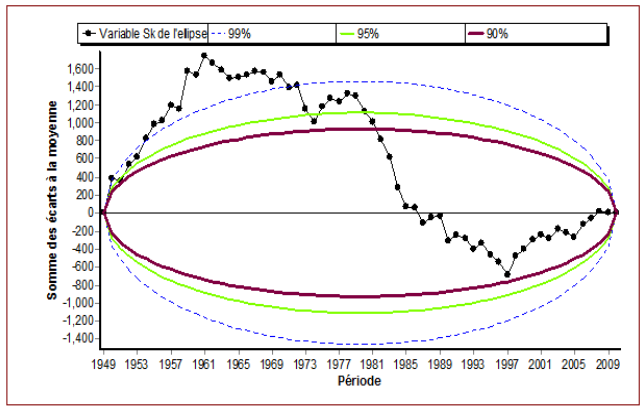

C. Ndjamena rainfall Station

Null hypothesis (No break) accepted at the confidence level of $99 \%$

Null hypothesis (No break) rejected at the confidence level of $95 \%$

Null hypothesis (No break) rejected at the confidence level of $90 \%$

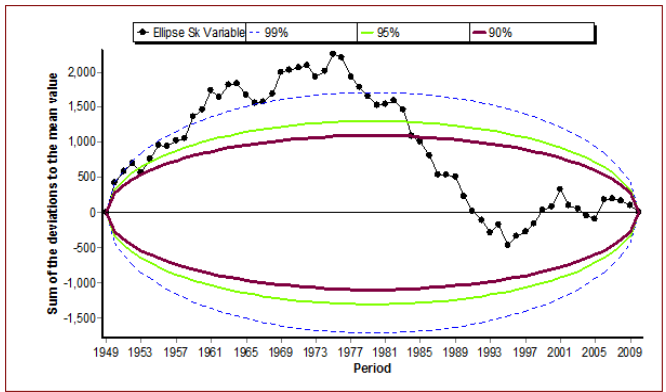

D. Sarh rainfall station

Null hypothesis (No break) rejected at the confidence level of $99 \%$

Null hypothesis (No break) rejected at the confidence level of 95\%

Null hypothesis (No break) rejected at the confidence level of $90 \%$

Figure 3: Buishand's test and Bois's ellipse.

today only the southern part of the basin is hydrologically active, the hydrological variations of the lake in the past must be considered throughout its entire orographic basin. Indeed, once the threshold of the Bahr El Ghazal is exceeded at $286 \mathrm{~m}$, the current lake will flow towards the northern part in the Djourab region and towards the depression.

\section{Impacts of climate change on lake chad}

Inevitably, the droughts of the Sahel in 1960-1970 and 1982-1984 and the construction of dams in Nigeria (neighboring Chad) drained the lake from its waters and made fishing activities difficult, Agriculture and livestock sectors exposing many populations to vulnerability. The number of fish species present in the Middle Lake Chad was estimated at 128, divided into 25 families (Lévêque, Paugy, 1999). During this period, fish benefited from several advantages due to the relative humidity in the basin (large well-ventilated open water areas, refugia in edge vegetation for juveniles, good reproductive conditions in floodplains for Migratory), but also suffered some constraints, such as the increase in salinity in the northern basin (unsuitable for certain species such as mormyridae). The term 'environmental change' here refers to the context specific case of the Lake Chad basin in terms of decline in water quantity and quality following the shrinkage of the Lake Chad [11].

Fishermen exploit various water bodies seasonally, yet increased fishing activities have not led to increased catches. FAO [12] reported a decrease from 220,000 tonnes of fish in the 1960s to about 100,000 tonnes in 2,000. Recent annual yields are placed at 50,000 to 60,000 tonnes. Similarly, low outputs have been reported for crops (e.g., sorghum declined from 328,000 tonnes to about 180,000 tonnes between the late 1960s and the years following 2010) and livestockdeclining at nearly $2 \%$ per year since the 1960 s [13].

With the passage of Small Lake Chad and the extension of the swamps which characterizes it, the space in open water has become limited, the lack of oxygen in the marshes. The floodplains have been little or no flooded, which has reduced the breeding of many migratory species, including the Salanga (Alestes baremoze).

In January 2008, there were more than 1.5 million waterbirds of about 70 species, with a majority of Palaearctic ducks $(64 \%$ of the population) supplemented by Afro-tropical Anatidae (18\%), (17\%) and other species. The numbers of most species experienced a significant increase in the 2000s, probably due to improved rainfall in the catchment area from 1998 [14]. 

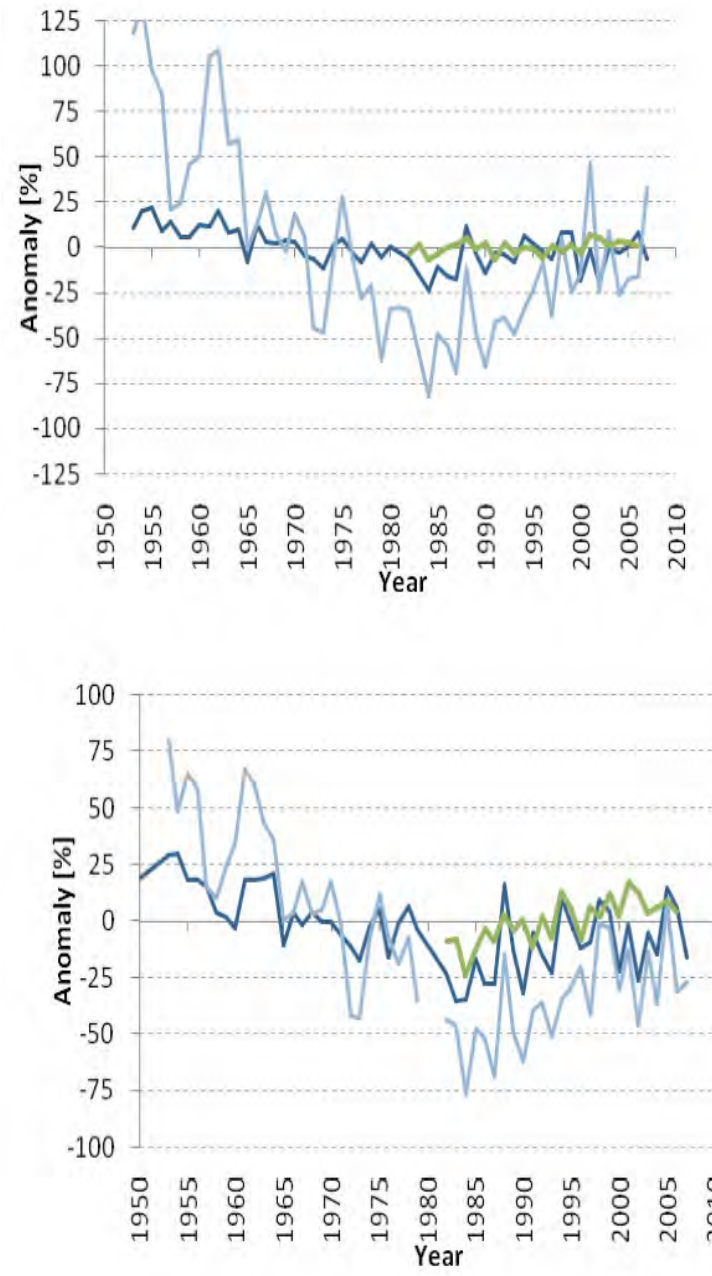

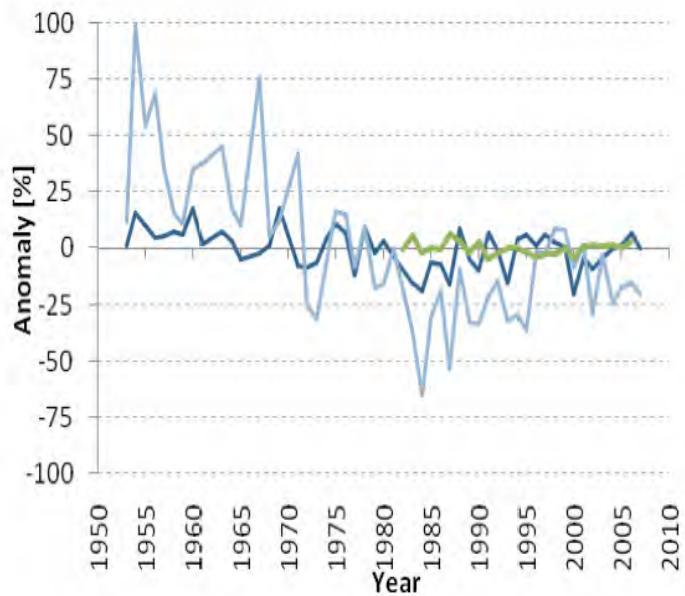

Anomalies: Catchment Means

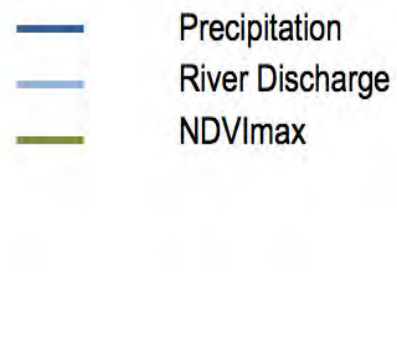

Figure 4: Anomalies calculated from annual means for selected watershed areas: Chari watershed at Mailao (UL), Logone watershed at Logone-gana (UR), and Bahr Azoum watershed at Tarangara (LL).

In this situation, people living around the Lake Chad basin are not spared, malnutrition strikes hard at 20 to 30 million people, which according to UNICEF estimates depend on Lake Chad and spread over four countries (Chad, Niger Nigeria, and Cameroon) [15]. In this article, we note that at the regional level, food insecurity affects Sahel regions more than in the south of the country. Indeed, the regions of Barh El Gazal; Borkou; Kanem; Batha; Guerra, Ennedi have proportions of food insecure households exceeding $40 \%$, which is very high. Compared to last year in the same period (October 2016), food insecurity rates are falling in almost all regions of the country except for Borkou, Ennedi, and Kanem, which have seen increases of more than $10 \%$ in one year.

The situation remains critical in the Lake Chad region, where the food insecurity rate of the displaced population rose from $15.4 \%$ in March 2016 (EFSA) to 35\% in October 2016 (ENSA) they receive, mainly due to lack of land for agriculture, the ban on fishing, the collapse of livestock prices. This challenge can only be met through the adoption of coherent intersectoral policies that reduce greenhouse gas emissions to cope with the impacts of climate change in the agricultural sector while harnessing its potential in terms of the fight against poverty.
Water is an essential production factor in agriculture for both crop production and livestock production. The challenges of ensuring food security in Chad are daunting, and climate change only makes them even more difficult to overcome.

Agriculture is a key sector for a developing country, such as Chad, despite the impacts it faces, and adaptation will certainly be necessary to address climate-related challenges such as desertification, degradation of Land, drought, floods and water scarcity.

In addition, agriculture is the main source of income for the majority of the working population. These people are the most vulnerable, not only do they produce most of the food for Africa but they also have the weakest capacity to cope with climate change.

\section{Effects of climate change on water resources in chad}

Understanding the mechanisms and geographic models by which anthropogenic climate change affects the variability of water resources is crucial for sustainable development, environmental management, and human health. However, the availability of water and water is a major concern of the present study. The consequences of this rainfall variability on surface waters are evident in view of the importance of this resource, whose flow has ceased to be perennial in the dry season in 
Citation: Jun X, Bantin AB (2017) The Impact of Hydro Climatic Variability on Water Resources of Lake Chad Hydro Graphic Basin. Hydrol Current Res 8: 282. doi: $10.4172 / 2157-7587.1000282$

Page 8 of 10

some rivers such as Koumadougou Yobé, whose contribution to Lake Chad was d 'Approximately $0.5 \mathrm{~km}^{3}$ / year for the period 1990-2000 and the flow of Chari, the main source of water supply to the lake, was the lowest. If the situation did not return to normal, thanks to a succession of years of excess rainfall, other rivers could also see their flow stop in the years to come (Figure S2).

Because surface water supplies groundwater, groundwater has a double hydrodynamic consequence. The deepening of their roof reduces the potential of their replenishment by already reduced infiltration due to the decrease in rainfall and by the enormous evaporation of surface water due to the increase in soil temperature. Their faster drainage results in a reduction in low water flows and an increase in the rate of drying, which has led to a small flow of some large rivers feeding Lake Chad.

\section{Lake chad level variations}

Any minor change in precipitation causes a significant change in river flow. Before the droughts of the 1970s and 1980s, the level of Lake Chad was limited from 0.5 to $1 \mathrm{~m}$. Today, we see seasonal variations up to 2 meters and more. The fundamental problem of the reduction of the lake level is the interaction between the lake and the water, and the water between the lake and the aquifer. While seasonal rainfall is a seasonal rainfall. At lower ground water levels, its stabilizing influence is lost, also increasing water losses from the lake (Figure 5).

The interannual evolution of Lake Chad depends on the balance between inputs (rivers, rainfall) and losses (Evaporation, infiltration).

In the mid-1950s, Lake Chad had a large surface area of open water with an upper surface of $282.3 \mathrm{~m}$ and an area of $25,000 \mathrm{~km}^{2}$. At that time, the lake had no outlet.

During the period from 1954 to 1969 , the contribution of Chari (a main source of supply) was $81 \%$ of the total intakes, the total inputs supplemented by direct rainfall on Lake Chad was $14 \%$, and the contribution of small tributaries like El Beid and Koumadougou Yobé is $4 \%$.

Water losses are mainly due to evaporation (95.7\%) and infiltration from the lake into groundwater, which accounts for only $4.3 \%$. These

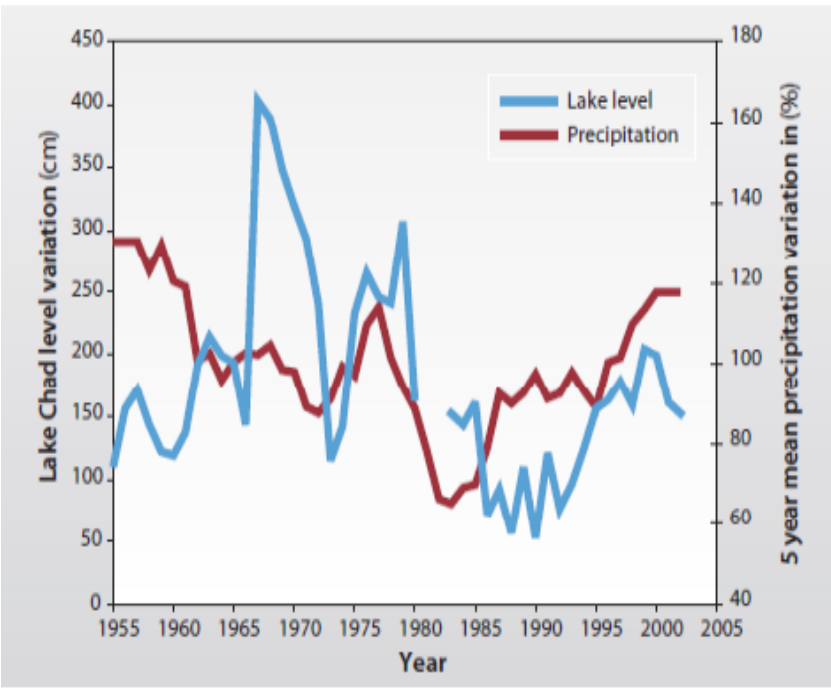

Figure 5: Lake Chad level variation and yearly precipitation at Bol. infiltrations are periodic and vary from one year to the other according to the multi-year evolution of the Lake Chad level and following the point of observation on the shore of Lake Chad.

For the period from 1988 to 2010, the observed relationship between river flow and rainfall in the Chari Basin indicates that for a $10 \%$ change in rainfall in the basin, the flow of the river varies by almost $30 \%$ [16] (Figure S3).

The lake is therefore very sensitive to climatic variations because the inputs are dependent on rain on the watershed (Figure 6).

\section{Discussion}

The analysis and interpretation of statistical data from the Bongor,

\begin{tabular}{|c|c|c|c|}
\hline Stations & $\begin{array}{c}\text { Breaking } \\
\text { years }\end{array}$ & $\begin{array}{c}\text { Probability of exceeding the } \\
\text { critical test value }\end{array}$ & $\begin{array}{c}\text { Level of } \\
\text { meanings }\end{array}$ \\
\hline Bongor & 1977 & $5.41 \mathrm{E}-04$ & significant \\
\hline Bousso & 1971 & $6.83 \mathrm{E}-04$ & significant \\
\hline Moundou & 1980 & $2.99 \mathrm{E}-02$ & significant \\
\hline N'Djamena & 1961 & $4.06 \mathrm{E}-03$ & significant \\
\hline Sarh & 1975 & $6.88 \mathrm{E}-03$ & significant \\
\hline
\end{tabular}

Table 4: Breakage of rainfall series according to the Pettitt test.

\begin{tabular}{|c|c|c|}
\hline Probability associated & Class & Level of significance \\
\hline$\alpha<1 \%$ & Very significant break & 0 \\
\hline $1 \%<\alpha<5 \%$ & Significant break & 5 \\
\hline $5 \%<\alpha<20 \%$ & weak break & 0 \\
\hline$\alpha>20 \%$ & Homogeneous series & 0 \\
\hline
\end{tabular}

Table 5: Level of significance of the results of the Pettit test.

\begin{tabular}{|c|c|c|}
\hline $\begin{array}{c}\text { Drought } \\
\text { sequences }\end{array}$ & $\begin{array}{c}\text { Duration } \\
\text { (months) }\end{array}$ & $\begin{array}{c}\text { Value of SPI (maximum } \\
\text { intensity) }\end{array}$ \\
\hline $1965-1967$ & 24 & -1.47 \\
\hline $1980-1987$ & 84 & -2.5 \\
\hline $2002-2003$ & 36 & -1.47 \\
\hline
\end{tabular}

Table 6: The severity of drought.

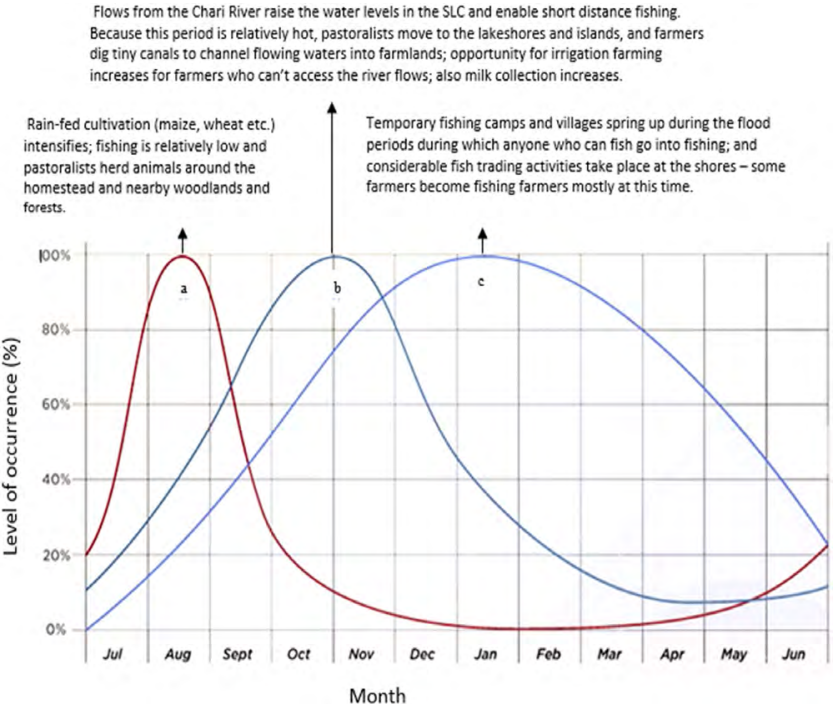

Figure 6: Annual flux of seasonal activities (based on Seasonal rainfall, River flows, and Water level/floods) observed during fieldwork at the southeastern shore of Lake Chad, 2013-2014. 
Bousso, Moundou, N'djamena and Sarh meteorological stations from 1950 to 2010 revealed rainfall variability and its impact on water resources in any form surface and groundwater of which Lake Chad pays a heavy price. The southern regions of Chad experienced a sudden break in the rainfall series over the last decade, particularly in the years 1982. These breaks show that this geographical area is influenced by fluctuations in the rainfall regime observed at the late 1960s and early 1970s in West and Central Sahelian and non-Sahelian countries. Indeed, the decline in rainfall can be explained by deregulation in the seasonal migration of the Intertropical Front (FIT) to the North. The result of this decline in rainfall was the low enrichment of surface water and aquifers.

Rainfall variability in Chad has been accompanied by a significant decrease in relative humidity and a rise in air temperatures, which has resulted in a hydrological cycle. It also manifested itself in the decline in rainfall, the reduction of rainy days, the extension of the dry season and the decline in the rainfall index.

Therefore, this rainfall variability influences the aquifers in terms of their water recharge and the feeding of Lake Chad. Indeed, since the rupture in the series of years 1982 the aquifers are experiencing real difficulties in the renewal of their water loads, creating a situation of water stress in Lake Chad. However, variances related to several parameters are observed. On the one hand, it is necessary to take into consideration the climatic factor. Given the impression of existing models on climate change and particularly for Chad, it is not possible to make forecasts on the hydrology of the Lake. The future close to Lake Chad thus depends essentially on the contributions of Chari, its main supplier of water [17]. The drying up of Lake Chad has accelerated with the drought of 1973 and 1984. However, an American article published in the Journal of geophysical research in 2001 explains that Lake Chad is threatened with extinction not only because of drought but also because anthropogenic irrigation which is estimated at more than $10 \mathrm{~km}^{3}$ per year. The reality also is that these $10 \mathrm{~km}^{3}$ represent half of Chari-Logone's annual intakes in the period 1994-2014 [18]. This is huge and it not surprising dramatic consequences on Lake Chad. Concerns are mounting, climate change and demand for freshwater and deficiency will create imminent problems within the Member States in shared hydrological units [19].

Given the situation, it is high time to come up with a creative solution to save Lake Chad which once considered the inland sea of Africa and which today has lost $90 \%$ of its surface area. If Lake Chad continues to decline at its current rate, this lake will disappear in about 20 years, according to NASA's climate forecasts [20]. The project currently being discussed by the Lake Chad Basin Commission (LCBC) and which has not been followed up, is to transfer $3.4 \mathrm{~km}^{3} /$ year of the waters of the Ubangi River, which originates in the Democratic Republic of the Congo Congo) to Lake Chad, though the rivers Chari and Logone. However, this project is far from making unanimity among the countries concerned. While the dramatic shrinkage of Lake Chad is itself a global disaster [21]. This requires concrete and urgent solutions not only by the LCBC (Lake Chad Basin Commission) and its members but also by the active support of the international community.

In this case, it is necessary to increase the water level of Lake Chad by creating an artificial rainfall in the area and to develop the drainage areas and then to create a reservoir dam in the Chari and Logone which would have the effect of limiting raw. This project to transfer water from the Ubangi River to Lake Chad will have an impact on the water resources of the Congo Basin and may give rise to legal and economic problems.
The option of creating artificial rain is not only an essential factor in boosting water resources in Chad but could also boost agriculture as well as livestock production. This production of artificial rain can lead us to a return to the paleo Chad [22-25].

\section{Conclusion}

The present study shows that over the past forty years Chad has experienced high climatic variability with a succession of dry and wet periods.

Analysis of the graphs shows that the precipitation at Bongor, Bousso, Moundou, N'djamena and Sarh stations are experiencing a significant downward break. Several ruptures have been detected in series whose causes are both natural and artificial.

The drying up of Lake Chad has resulted in a decrease in the flow of water into the watercourses of the region.

This decrease is marked by a very significant break in 1982 for most stations.

Although Lake Chad is located in a tropical humid climate, it should be noted that microclimates linked to atmospheric and floristic factors exist in Chad and cause the climate to vary. Studies on climate variability and change in Chad draw the attention of the world community to large-scale climatic events and among them the droughts of 1973 and 1982, which result in falling precipitation, piezometric levels, and the drop-in stream flows. These phenomena have caused massive displacement of the population, causing in some cases famine and loss of human life. Agricultural production has been declining linked to this climatic variability. A few years ago, it was only an ecological drama, today it has become a human drama. So, the urgency is to ensure that the Lake Chad basin becomes a pole of economic growth for the rural populations who live in this area. Thus, this article, which we have just written, puts forward a solution to save Lake Chad, which was once considered the inland sea of Africa and today has lost $90 \%$ of its surface area. In this case, it is necessary to strengthen the water level of Lake Chad by creating an artificial rain and to develop the drainage areas.

These results should serve as a source of reflection and reflection for Chad and for international opinion in the adaptation against global warming.

\section{References}

1. Gulick SPS, Jaeger JM, Mix AC, Asahi H, Bahlburg H, et al. (2015) MidPleistocene climate transition drives net mass loss from rapidly uplifting St Elias Mountains, Alaska. Proc Natl Acad Sci USA 112: 15042-15047.

2. Micalel T, Jonathan CAF (2001) Africa's Lake Chad Shrinks By 20 Times Due to Irrigation Demands, Climate Change-Science Daily, p: 2.

3. FAO (2011) Climate change implications for fishing communities in the Lake Chad Basin, What have we learned and what can we do better? Lake Chad Basin Commission Workshop, p: 31, N'Djamena, Chad.

4. Coe MT, Foley JA (2001) Human and natural impacts on the water resources of the Lake Chad basin. Journal of Geophysical Research 106: 3349.

5. Uche TO, Lindsay CS, Andrew JD (2016) Lake drying and livelihood dynamics in Lake Chad: Unravelling the mechanisms, contexts and responses. Ambio 45: 781-795.

6. Neiland AE, Sarch TM, Madakan SP, Ladu BMB (1994) Fisheries research priorities for international inland waters in west and Central Africa: A case study of the Chad Basin. A review paper for the 2nd dialogue meeting for the ACP-EU research Initiative. Dakar, Senegal.

7. Stauch A (1977) Fish statistics in the Lake Chad basin during the drought (1969-1976). Orstom, p: 201. 
Citation: Jun X, Bantin AB (2017) The Impact of Hydro Climatic Variability on Water Resources of Lake Chad Hydro Graphic Basin. Hydrol Current Res 8: 282. doi: $10.4172 / 2157-7587.1000282$

Page 10 of 10

8. Weltzin JF, Loik ME, Schwinning S, Williams DG, Fay PA, et al. (2003) Assessing the Response of Terrestrial Ecosystems to Potential Changes in Precipitation. BioScience 53: 941-952

9. Bryon RA (1973) Drought in Sahelia: Who or what is blame? Ecologist, pp: 366-371.

10. Urama KC, Ozor N (2010) Impacts of climate change on water resources in Africa: The Role of Adaptation. African Technology Policy Studies Network (ATPS), p: 8

11. Stringer LC, Okpara UT, Dougill AJ, Bila MD (2015) Conflicts about water in Lake Chad: are environmental, vulnerability and security issues linked? Progress in Development Studies 15: 308-325.

12. FAO Managing Biodiversity in Lake Chad Basin. Biodiversity for Food Security

13. Mekonnen DT (2016) The Lake Chad development and climate resilience action plan. Main report. Washington, DC: World Bank Group. Vol 2.

14. Trolliet B (2010) à paraître - "Faune caractéristique". In: Magrin G, Pourtier R, Lemoalle $\mathrm{J}$ (ed.), Atlas du lac Tchad.

15. UNICEF: Bloemen S (2011) Lake Chad's receding water level heightens risks of Malnutrition and disease.

16. Lemoalle J (2014) Le développement du lac Tchad: situation actuelle et futurs possibles, p: 38
17. Samsons YA, Onyekakeyah L (2008) Lake Chad, once upon a time: the vulnerability of Africa's shrinking lake. Editorial office, Guardian Newpaper Isolo Road, Logas, p: 3.

18. Dop J, Piercy P (2016) Le mythe de la disparition du lac Tchad. Les Cafes Geo, p: 4.

19. Asah ST (2015) Transboundary hydro-politics and climate change rhetoric: An emerging hydro-security complex in the Lake Chad basin. Wiley Interdisciplinary Reviews: Water 2: 37.

20. FAO (Centre D'actualites De L'onu) (2009) L'assechement du lac Tchad menace les moyens d'existence des riverains- FAO.

21. Pouyaud B, Colombani J (1989) Les variations extrêmes du lac Tchad L'assèchement est-il possible? Anales de Géographie No545 XCVIII, p: 17

22. Ngatcha BN, Lemoalle $J$ (2014) Variabilité des paysages et de la biodiversité du lac Tchad. Marseille: IRD, p: 105.

23. Field F (2007) Climate Change, Impacts, Adaptation, and Vulnerability. Contribution of Working Group II to the fourth Assessment report of the Intergovernmental Panel on Climate Change, Cambridge: Cambridge University Press, 2007.

24. Inter-Governmental Panel on Climate Change (2007) Climate Change 2007. Synthesis Report (IPCC, Geneva). Contribution of Working Groups I, II and III to the Fourth Assessment Report of the Intergovernmental Panel on Climate Change. Vol. 7. Geneva, Switzerland: IPCC; 2007.

25. Li Y, Urban MA (2016) Water Resource Variability and Climate. Water 8: 348. 